DOI: https://doi.org/10.47405/mjssh.v6i7.844

\begin{tabular}{|c|c|}
\hline 4 & Malaysian Journal of Social Sciences and Humanities (MJSSH) \\
\hline $\begin{array}{l}\text { Malaysian Journa of } \\
\text { Social cciences and }\end{array}$ & Volume 6, Issue 7, July 2021 \\
\hline (MJ-sSH) & e-ISSN : 2504-8562 \\
\hline & $\begin{array}{l}\text { Journal home page: } \\
\text { www.msocialsciences.com }\end{array}$ \\
\hline
\end{tabular}

\title{
A Legal Perspective on Academic Plagiarism of Research Writing in Malaysian Universities
}

\author{
Muhamad Ikhwan Mohd Zain ${ }^{1}$, Nur Ezan Rahmat ${ }^{1}$, Mohd Naqiuddin Zulkarnain ${ }^{2}$ \\ 1Faculty of Law, Universiti Teknologi MARA (UiTM), Shah Alam, Selangor, Malaysia \\ ${ }^{2}$ Academy of Language Studies, Universiti Teknologi MARA (UiTM), 26400, Pahang, Malaysia \\ Correspondence: Muhamad Ikhwan Mohd Zain (ikhwanzaeen@gmail.com)
}

\begin{abstract}
Plagiarism is acknowledged as dangerous, especially when academicians are accused of being engaged in malpractice in publishing their research papers. The increased amount of online access to research led to academic dishonesty and plagiarism rising in higher learning institutions. It is challenging to balance the academic and public interest demand with the intervention of globalisation in education, which introduces the hegemonic world ranking universities. Plagiarism has resulted in the unoriginality of research outputs which can affect the knowledge in the future. It also resulted in the academicians abusing their honour while writing research papers in whatever discipline of knowledge. This is a severe problem that needs a quick reform to the legal framework. From the qualitative data, the study believes that by having a proper provision relating to plagiarism in the legal framework, especially for the academicians, plagiarism cases in the educational institution may be reduced. The current existing policies and guidelines should be inserted directly into any relevant Act or rules and regulation to be imposed on the parties involved. The government needs to produce a fair and standard provision on plagiarism in dealing with the weaknesses or loopholes in the educational institution policies and regulations for academic integrity to be upheld.
\end{abstract}

Keywords: academic plagiarism, research plagiarism misconduct, legal framework

\section{Introduction}

The world is moving towards the 21 st century, whereby all technologies are utilized in daily routines, including the information or knowledge available online. Too many sources can be referred to on the internet by only typing it out and clicking on it, then the person may just quickly "copy and paste" any information they need. This helps the person, especially a researcher, finish his research paper faster, but it has resulted in plagiarism misconduct (Mustapha et al., 2017). It is a well-known fact that plagiarism has occurred since a long time ago, and it is immersed to be more negative either in the practice of the students or the academicians. Furthermore, it is such a norm in universities for academicians to publish research papers as part of an indication into the world of paper ranking and academic competition. Instantaneously, this has resulted in a decrease in the quality and value of the research. Even when software such as 'Turnitin' is produced to detect plagiarism, it is still easier for everyone to cheat and plagiarize anything with the aid of the internet.

Generally, academic plagiarism is a serious and complicated issue, even at the faculty level. The problem can be better dealt with if all concerned parties are willing to take proper and proactive 
activities (Sonfield, 2014). Therefore, this study suggests that there should be a standard provision in any of the existing law that discusses the academicians' perspective who is also actively involved in plagiarism. As India has been referred to as the benchmark country in the previous research (Mohd Zain et al., 2021), this paper would like to extend the reference to Indonesia in dealing with plagiarism. Adiningrum (2015) stated that Indonesia struggles with plagiarism in educational institutions though being a significant player country in Southeast Asia. Therefore, the top management acknowledged that in addition to a detection mechanism and awareness to successfully discourage plagiarism, a complete and effective policy defining the definition, detection, and sanctions should be in place.

That being said, the Malaysian Ministry of Higher Education (MoHE) can examine current regulations and take certain actions similar to what Indonesia has done. It is such a crucial matter to be brought into action, as having no provision to curb the plagiarism act, which the academicians do in all institutions, might result in the unethical practice of writing and breach of academic integrity.

\section{Literature Review}

Previous studies have stated that academicians should be given a specific prohibition clause to show that they are not immune to plagiarism in their research and its legal consequences if they are found doing so (Mohd Zain et al., 2021). As a matter of fact, it is undeniable that the academicians may still be engaged in improper behaviour, malicious misconduct, or an intentional breach of a law or norm of conduct even they are treated as a professional human being (Ali Mohamed et al., 2019). This is proven by Olesen et al. (2017), where the team has identified many types of research misconduct in the academic world, and plagiarism is considered one of such.

First of all, plagiarism itself has many definitions depending on the countries and between the authors of the previous articles (Aziz et al., 2020). For example, in its chapter I, article 1, unit 1, the Indonesian laws defined plagiarism as an act that either direct or indirect attempt to obtain credits or marks from a research paper by copying others' work, either explicitly or implicitly, and presenting it as one's own without properly and adequately citing the source (Akbar \& Picard, 2019; RPMPHE 2010). Besides, Saha R. (2017) has also classified plagiarism as an act of infringement of copyright and authorship right, but the difference is that plagiarism has a smaller scope of the area, covering only academic ethical matters or also known as academic cheating. In contrast, the Chancellor of Universiti Sultan Azlan Shah has described plagiarism as "an academic crime" where it involves the act of stealing others' idea without any permission. He further said that such dishonourable action against knowledge and intellectuals should be firmly addressed (Shaarani Ismail \& Muhammad Zulsyamini Sufian Suri, 2017).

Above all, the formal definition has been provided under Rule $8 \mathrm{~A}$ of the Educational Institutions (Discipline of Students) Rules 1976 (Mohd Zain et al., 2021). Some universities have also defined the term 'plagiarism' in their way and mostly are provided under the rules or policies. The IIUM Staff Disciplinary Rules 2015, for instance, has mentioned plagiarism under section 19(1) and clearly expressed that a staff member shall not plagiarize another person's intellectual property and cannot commit any action which falls within the scope under subheading 2 (a) to (h). Aside from that, the USM Policy on Plagiarism (2017) also highlights the meaning of plagiarism through Para 2.4, where it is referred to as "the act of presenting, quoting, copying, paraphrasing or passing off of ideas, images, processes, works, data, own words or those of other people or sources without proper acknowledgement, reference or quotation to the original sources".

All definitions which are previously provided have clearly shown that the higher educational institutions have acknowledged that plagiarism is a challenging case and may harm the reputation of the institutions themselves (Mohamed et al., 2018). It has worsened since such plagiarism occurs among academicians who have failed to produce their original work of academic writing and are freely copying the students' work to be published as their papers (Moten, 2014) for their benefit, thus making the integrity level of academicians to become questionable. Nonetheless, the development of plagiarism misconduct in academic writing needs to be stopped before it can further mislead the facts 
and information of any particular knowledge research. Mohamed et al. (2018) has argued that a good researcher should have the ability to research in full of interest so that the issue of plagiarism shall be combatted quickly.

Surprisingly, the qualitative data in the research which are conducted by Olesen et al. (2017) has proven that plagiarism by academicians has gotten the highest and most common answer by the respondents. This is in disparity with the Malaysian government's national agenda and the National Higher Education Strategic Plan (NHESP) to generate a first-class human mentality to adapt to the evolving challenges in knowledge and innovation-based economy in the upcoming time (Mohamed et al., 2018). Therefore, it is agreed by Kannan (2019) that this immoral practice of plagiarism must be investigated, and equivalent action must be taken on the culprits, as per what is mentioned by the Minister of Education.

However crucial the cases of plagiarism are in Malaysia, they have happened not only within the country, but this plagiarism misconduct has also threatened many other countries. On the bright side, most of them have already started to address this peculiar misconduct (Singh, 2015; Mustapha et al., 2017; Ahmed, 2020). Although it is not a simple issue as it involves the professionals, especially among the faculty members (Sonfield, 2014), it is critically essential to impose and enforce the related legal provision to those who have plagiarized in their construction of published academic writings.

The authors are interested in using Indonesia as a model nation. In the case of Indonesia, for instance, with the introduction of The Act of the Republic of Indonesia Number 20 the Year 2003 under the National Education System (ANES 2003), the Indonesian government has developed many following regulations pertaining to plagiarism in the national education system (Akbar \& Picard, 2019). According to the form of plagiarism they have committed, the faculty members can either be punished by repealing their position, be fined, or up to the extent of imprisonment, according to the form of plagiarism they have committed (Wijaya \& Gruber, 2018). The copyright law in Indonesia has also recognized the offence of plagiarism to be included as one of the copyright infringement (Wibowo et al., 2016). Thus, it is agreed that the issue of plagiarism may be taken into the eye of the law, and therefore the educational institutions should be adopting a proper provision on the matter.

\section{Methodology}

This study adopts the qualitative approach based on doctrinal library research and in-depth interviews. As the previous research has mainly focused on library research (Mohd Zain et al., 2021), the current study describes the academicians' opinions and knowledge by voluntary in-depth interviews with a few chosen academicians in Malaysian universities. It is also substantiated by data and information from supplementary sources such as journals, publications and websites. The pilot test is also conducted in helping the design of the questionnaires to create good questions (Olesen et al., 2017).

Similarly, the population area of this study is maintained within the three firstly selected Malaysian universities, namely International Islamic University Malaysia (IIUM), Universiti Teknologi MARA (UiTM) and Universiti Sains Malaysia (USM). The interviews are conducted with legal professionals on a voluntary basis to better understand their institutional policies or regulations on academic plagiarism. As the movement in Malaysia is still restricted by the Movement Control Order (MCO), which is currently being enforced, the interviews are conducted online, with a period of about 30 minutes for each session, using a suitable, preferable and comfortable language of the respondents.

In addition to the library research and the usage of keywords such as academic plagiarism, research plagiarism misconduct and legal framework, several interviews are also conducted as a method of reasoning that moves from a specific instance to a general conclusion. Usually, having several respondents from various backgrounds and knowledge with different responses can generate new theories and a new pattern for the current research. 
In asking for opinions and experiences on the research misconduct through in-depth interviews using semi-structured questionnaires, the research has identified several relevant respondents. The similar method has also been used by previous researchers (Olesen et al., 2017). In prior to the session, the questions have gone through a validation process. An expert review is done, followed by a short pilot project to assess the validity of the questions and their terminology, phrasing, and relevance (Majid et al., 2017). Then only, the authors contacted the respondents through email or giving them a call. The agreed respondents decide the best date and time to conduct the semi-structured interviews. Since it is a flexible session with the respondents, the researcher has prepared several sets of questions that may be changed according to their responses. It is a decent method in collecting the data, as it can go into depth and accommodate the unexpected and emergence data.

Based on the outcomes from the primary information, which are the library-based research and interview sessions, all the data are analyzed and arranged accordingly. The oral interview sessions from all the respondents are also put into written forms. The research believes that by having a differentiated background of respondents for the interview, the outcomes might also be different. A comparative method is further made between the respondents' responses, and it is analyzed to cope with the library findings. This is done to determine the general pattern of the highlighted issues by the respondents (Olesen et al., 2017) and to compare while also defining the significant findings to test their validity. During the final assessments, no new evidence or facts have appeared, suggesting that the primary data has been attained; it is necessary to keep in mind that respondents' views cannot be applied to the larger Malaysian academic population. The interview questions will have highlighted the topics relevant to the researchers (Olesen et al., 2017) and, at the same time, investigating the possibility of research misconducts in their institutional organization.

\section{Result - The Legal Framework}

The findings of this study have merged the respondents' opinions with the facts that are found in the literature review. It is agreed that all academicians, or even students at higher education institutions, must put precautions and very great attention to this exceptional problem as it may contribute to a significant impact on the future of research writing. At present, within the era of technological advancement, the visibility and easily accessible writings on the internet will eventually lead to unethical and misconduct of any person, including the academicians, who tend to plagiarize the information available and is then claimed to be theirs. This study is in conformity with Olesen et al. (2017) that many other Malaysian universities have laid procedures in place to regulate research misconduct, including plagiarism; however, the effectiveness of these mechanisms and whether researchers are aware of them seem controversial.

In Malaysia, the Ministry of Higher Education always deals with matters pertaining to tertiary students such as Public Universities, Private Higher Educational Institutions, Polytechnics, and Community Colleges. They have enacted some relevant legislation; among others, the Universities \& University Colleges Act 1971 (Act 30), the Private Higher Learning Educational Institutions Act 1996 (Act 555), and the Educational Institution (Discipline) Act 1976 (Act 174), which are currently available for the educational institution in Malaysia (Mohamed et al., 2018; Ismail et al., 2012; Mohd Zain et al., 2021). Nevertheless, with all the accessible legislations, this study has opined that the government still need to put an extra effort to inject the plagiarism problem among academicians into the legal framework. In dealing with plagiarism in academic writing, it is the duty and the power of MoHE to regulate relevant laws relating to education at Parliament. Mohamed et al. (2018) have intended that the Minister is the one who should propose the legislation on educational matters at the Parliament, as the ultimate authority, which will then become one of the many sources of educational laws for academicians, academic administrators, while also applicable to all parties at all educational institutions.

Astoundingly, the research has identified that only Act 174 is injected with the discussion on plagiarism as one of the disciplinary offences, yet it explicitly focuses on the students (Mohd Zain et al., 2021). On the other hand, several institutions such as UiTM, IIUM, and USM (Mohd Zain et al., 2021) have further discussed plagiarism in their institutional rules and policies. 


\section{Universiti Teknologi Mara (UiTM)}

UiTM is one of the institutions which take serious action in combating any academic misconduct among its members. UiTM has a significant advantage in implementing plagiarism law to students since the institution itself has provided an explicit provision relating to plagiarism under Rule 8A of the Educational Institutions (Discipline of Students) Rules 1976. Also, from the Research Ethics Committee (REC) establishment, UiTM has aimed to achieve a high quality of research outcomes with strict procedures. Simultaneously, the integrity, dignity and right of the research can be established, as the "UiTM Plagiarism Policy and Its Implementation" can be read together with the Educational Institution (Discipline) Act 1976 (Act 174). Nevertheless, one of the respondents has suggested that there must be an additional regulation for academicians in supporting the policies to combat plagiarism issues among them. He has also emphasized that plagiarism still one of the critical issues under the primary responsibility of the institutions, which must be catered to comprehensively and effectively. Additionally, he opines that these inappropriate acts of plagiarism, which are done by academicians, should be considered as severe abuse in the field of knowledge. Academic plagiarism, therefore, shall be subjected to suitable punishments through proper implementation of the legal framework. The government may revisit the provision to allow and consider widening the current section's scope.

\section{International Islamic University Malaysia (IIUM)}

Aside from UiTM, the IIUM Staff Discipline Rules 2015 is also specifically enacted to govern any disciplinary issue concerning the staff, conferred from the powers under Article 40(1)(e) of the IIUM Constitution itself. Under Rule 19(1), it is clearly expressed that a staff member shall not plagiarize another person's intellectual property (Mohd Zain et al., 2021). Therefore, an academician cannot commit any action that is enacted under subheading 2 of Rule 19, starting from (a) to (h) as it is referred to be included as an act of plagiarism. If the staff is caught committing plagiarism, he could be punished under Rule 29, which is listed from any listed sanctions. By inserting plagiarism as one of the provisions, it is an indication of the university's seriousness to combat such academic misconduct among their staff. However, even the rules do not provide a complete plagiarism procedure; the IIUM institution has put a reasonable effort in inserting the conduct of plagiarism as one of the prohibitions in academic misconduct to maintain their members' academic integrity.

The respondent has added that even some people argue that it is unnecessary to have a proper law on plagiarism as it is often viewed as morally wrong, but for him, it could also be well-thought-out as legally inappropriate. Most importantly, the respondent proposes that academic integrity should be upheld. The right of the public is treated fairly and squarely by implementing the strict rule on academic plagiarism. He has also revealed one example of such cases that have happened, where the student's work is being taken into the supervisor's advantage and is published as his research, without any acknowledgement to the student himself. If there is even some form of consent provided by the student, there will be no question of plagiarism at all. As students are the reflection of the lecturers who taught and guide them while studying, it is a massive responsibility for academicians to have high integrity inside themselves. Before this kind of things worsens, the respondent indicates that having a proper law is the best possible way to devour early prevention of the misconduct.

\section{Universiti Sains Malaysia (USM)}

Comprehensively, the USM Policy on Plagiarism applies to all students and staff, including academic staff, non-academic staff, research staff, contract staff, fellows, post-doctorates, visiting scholars who study, serve or graduated from the University, as stated clearly in the policy. This shows that USM is immensely concerned with academic integrity, and therefore the application of this policy is applied entirely to all the institution members (Mohd Zain et al., 2021). The respondent agrees with this in the interview session. He has contended that not many institutions have currently formed a comprehensive guideline and policy that would significantly serve the issue.

The precise definition of plagiarism under para 2.4 gives all the parties a better understanding of determining whether or not the act falls within the ambit of plagiarism. As this policy only has small 
legislative authority, it shall be read together with the Universities and University Colleges Act 1971 (Act 30), Statutory Authority (Discipline and Surcharge) Act 2000 (Act 605), USM Constitution, and also other relevant statutes, rules and regulations of the University. The research has also observed that this significant policy offers a clear and thorough discussion in dealing with plagiarism problems in the University. Therefore, the respondent contends that this policy can be a strong model and a template for all educational institutions. He has also admitted that this is the time for the institution to have a whole official document from scratch to the final result, which independently discusses the issue of plagiarism.

Mohd Zain et al. (2021) have analysed the existing legislation and concluded that no proper parent law prohibits plagiarism as misconduct among academicians. Hence, a common-law on plagiarism in all institutions should be established. This is important to avoid confusion and misunderstanding among the members of Malaysian universities (Eret \& Gokmenoglu, 2010).

Table 1: The Malaysian Institution and the Law

\begin{tabular}{lccc}
\hline Category & UITM & IIUM & USM \\
\hline $\begin{array}{l}\text { The legal } \\
\text { framework }\end{array}$ & $\begin{array}{c}\text { Educational Institution } \\
\text { (Discipline) Act 1976 } \\
\text { \& UiTM Plagiarism } \\
\text { policy }\end{array}$ & $\begin{array}{c}\text { IIUM Staff } \\
\text { Disciplinary Rules }\end{array}$ & $\begin{array}{c}\text { Universiti Sains } \\
\text { Malaysia Policy on } \\
\text { Plagiarism }\end{array}$ \\
$\begin{array}{l}\text { Legislative } \\
\text { Authority }\end{array}$ & Primary legislation \\
$\begin{array}{l}\text { Relevant } \\
\text { provision }\end{array}$ & $\begin{array}{c}\text { Rule 8A in the Rules } \\
\text { under the Act }\end{array}$ & Subsidiary legislation & $\begin{array}{c}\text { A document } \\
\text { complies with } \\
\text { existing law }\end{array}$ \\
Application & Applicable to student & Applicable to staff & $\begin{array}{c}\text { Applicable to staff } \\
\text { and student }\end{array}$ \\
\hline
\end{tabular}

Source: Mohd Zain et al. (2021); Ismail et al. (2012); Mohamed et al. (2018)

All in all, some universities have taken a step ahead to ensure that the members are applying academic integrity within their institutions. It is a good method to have the rules and policies, but the scope of discussion in the law may be improved and can be better if there is a uniform law across all institutions. While the educational institutions in Malaysia have various existing legal frameworks in dealing with their development, yet the law is still not significant enough. Therefore, the government has to put an extra effort into the relevant provisions in dealing with academic plagiarism.

\section{The Case Law}

Pertaining to case law, the cases of plagiarism have not gotten much attention in the Malaysian court as most of the time, the issues are settled at the university level. The research acknowledges that academic plagiarism in Malaysia is treated differently from the legal perspective, as there is no clear law to govern the issue, and therefore the legal action is not usually taken before the court (Mohd Zain et al., 2021). The court's institution has also admitted that the cases are handled by the internal administrators subject to where the cases have happened. It is only after the proceeding is settled in their exact universities that if any irregular proceeding has taken place or there has been such defamation, it can be brought to the court, but this kind of things have happened only once in a blue moon.

Additionally, the decided case of Fauzilah Salleh v Universiti Malaysia Terengganu [2012] 4 CLJ 601 has only emphasized the definition of plagiarism. It is noted that this case does not discuss the matter of plagiarism as a whole, but the court, in general, has mentioned the term to elaborate the case further and for the university to take serious action on this plagiarising problem (Mohamed et al., 2018). Likewise, in 2018, The Malaysian Court has once decided in the case of Abu Hassan bin Hasbullah v Zukeri bin Ibrahim [2018] 6 MLJ 396 that one of the professors is to be proven guilty of plagiarism 
offence. Although the case was entirely discussed from the tort law perspective, particularly on defamation and libel, the court has held that the defendant successfully justifies the issue of plagiarism and proves that the plaintiff's PhD thesis entitled 'Film as A Lens of Cultural Identity: A Critical Analysis on Malaysia Film' is copied directly from the writing of Viola Shafiq's book of Arab Cinema.

Another interesting case regarding plagiarism that is brought to the Industrial Court of Malaysia to determine whether the employee's dismissal as a lecturer amounts to lawful dismissal is Priya $K$ Krishnan v Sunway University College [2019] 15/4-1337/12. In this case, the judge has considered plagiarism to be serious misconduct and is not acceptable in the academic sector, as plagiarism leads to academic dishonesty and a breach of journalistic ethics, which put a high risk to the Company's reputation as a university. The case is started when the lecturer claims that the slides note for her class material belongs to her, but it is proven that she has completely plagiarized other's work. Due to her misconduct, the trust and reliability of the university have been breached. Thus, the court allows her dismissal as a lecturer in the university. Even though plagiarism in this case only involves the slide notes of certain teaching material, it can still amount to the dismissal of the academicians since it has breached the provision stated in the university's rule, should there be any.

Beyond everything, the research believes that academic integrity, especially in writing, should be put in a higher position, as it portrays the level of knowledge in society. The more knowledge a person has, the more ethical and honest he should be. In achieving that, the legislation is proposed to be one crucial instrument to control and deter academicians from doing such an unethical act. The study is enthusiastic in promoting academic integrity among the members of the Malaysian educational institutions; plagiarism should be encountered seriously through the lens of a legal perspective.

\section{Discussion}

The research has focused on the legislation provided under the Ministry of Higher Education and identified a few Malaysian institutions that have provided the plagiarism rules or policies in detail. The respondents' interview findings are also analyzed to consider their opinion of having such a proper law and standardization to all institutions. Even so, many other universities in Malaysia still do not have such a framework (Mohd Zain et al., 2021). The research acknowledges that the parent law, which the aforementioned educational institutions currently use, has no relevant role to play in addressing academic plagiarism as a whole. If the government can further discuss the Act's power to deal with this problematic matter, it will then be considered as a good solution. As the only significant Act is Act 174 , it should be cross-referred with all the existing rules and policies to make it more comprehensive and relevant. The government may combine all these provisions accordingly and produce a uniform and standard law in all institutions (Mohd Zain et al., 2021).

The findings have also shown that the legislative power conferred by the parent law does not have many effects to combat the plagiarism issue and promoting academic integrity in research writing. In USM, for instance, the respondent and his research team have done their best in upholding the integrity of the staff to the highest level. This can be seen starting from 2011, and the policy is revised in 2016 to improve the inclusiveness of the content. The respondent also believes that academic integrity should be maintained and honesty should be strengthened in achieving excellence in the educational institution. Notwithstanding the use of plagiarism detection software, the policy is applicable to regulate all parties, including students and academicians, if there is any infringement of the issue in academic writing. The research, moreover, believes that if the authority can take the responsibilities as serious as what has been done by the USM members, the objectives of the Malaysian government to produce a first-class human mindset may be achieved. Also, this research does not deny the importance of spreading awareness on ethical aspects and the use of plagiarism detection software, but in addition to it, the government should provide a stricter policy to every educational institution in Malaysia to combat the plagiarism issue. Though the current legislation is relevant, it requires a lot of improvements (Mohd Zain et al., 2021). 
Referring to Indonesia as one of the countries facing the same problem (Aziz et al., 2020), the government there has taken a few initiatives where their Education Ministry introduces abundant of policies following the ANES 2003 as the national policy. Among others, the National Education of the Republic of Indonesia Regulation, Number 17, 2010 on Prevention and Mitigation of Plagiarism in Higher Education (RPMPHE 2010), circular letters, ethical or honor codes and guidelines. All these efforts are made with the intention to strengthen the importance of having policies in combating the plagiarism offence in the academic world as the social agent for academic integrity (Akbar \& Picard, 2019). The RPMPHE 2010 policy even includes all parties from university students, faculty, and professors up to the university leaders to be punished for plagiarism. Before the cases start to burst and overwhelm, they believe that the stakeholders should ensure that a proper regulation exists in combatting or at least minimizing plagiarism in academic writing. In any respect, good research practice by academicians requires the highest professional ethics level with a critical and open-minded research method. As fellow academicians, they should not be applying any academic misconduct that can breach the academic writing's honesty and fairness.

Meanwhile, in Malaysia, plagiarism is not yet considered as civilly wrong conduct but rather disciplinary misconduct; thus, no consequential case proceedings are brought to the court. Most of the time, the local educational management would rather deal with the alleged issue privately (Abdul Hamid et al., 2015). There is nothing wrong with handling the issue in such a way, as it has to be understood that it reduces the backlog of cases in court. However, the outcome of the proceeding within the walls of the university boards shall be made public to ensure the transparency of the system while acting as a deterrence for other academicians not to do the same. While the law is in place, the enforcement can totally be carried out. The best way in dealing with the problem is to start from the core. The implementation of the law itself can lead to a better understanding of the regulations, sending a direct message of the importance of having a great awareness among the parties in all educational institutions.

Also, it is dejecting to know that the allegation of practicing plagiarism is also as stressful as breaching the copyright, especially when it involves professional careers such as academicians. The copyright has its own enacted provision of law. At the same time, plagiarism still maintains to be as old and perhaps more subjective as the discussion is only on the ethical and disciplinary matter rather than the legal perspective. Therefore, academic plagiarism should also be given a clear way to be taken into action, as similar to copyright issues. The act of copying, taking others' idea and claiming the writing as his own have involved so many breaches of trust, respect of the professional person's responsibility, up to the level that it has amounted to as one kind of corruption levels. Even the news can be fake in today's world; no surprise if academic writing is 'faked' too (Harvey L, 2020). Consequently, it is not a healthy practice to be accepted just to fulfil the research writing requirements of the universities.

The study has objectively emphasized the importance of exercising pure and honest integrity while upholding justice, which everyone is just the same before the law. It cannot be denied that these cases have occurred within only the educational institutions and not for public concern, but being an academician who is working at a professional level, honesty and integrity should be manifested accordingly. As it has been discussed earlier, this study suggests imposing a civil action to the court against the academicians who have committed plagiarism, in addition to the university's disciplinary action. The existing Rules or Acts should be elevated to a top-quality level by inserting the matter of academic plagiarism in any relevant parent Act. Amendments should be made to the existing legal framework to include the provision specifically dealing with plagiarism issues among academicians. If no action is taken, the problem will definitely keep existing and continuing. A fair educational policy should be imposed on everyone, disregarding any individual's superiority and power so that justice and equality can be established in the institution (Zejno, 2019). The legislation, policies and rules should be enhanced and tightened to deal with the emerging plagiarism cases among all parties, whether they be the academic staff or the students (Mohd Zain et al., 2021). 


\section{Implication}

Plagiarism is an issue that is not something light and small, as it can eradicate the public's trust and respect towards the educational institutions. Paramount amendments need to be done to the Malaysian law, as there are gaps in imposing the relevant legislation on the stated matter. In doing so, the punishment may be more severe to deter any of the professional people from committing such plagiarism misconduct in silence. After all, the expected advantage is that all higher educational institutions in Malaysia may refer to a standard and published regulation involving academic writing misconducts, precisely academic plagiarism in research writing that provides clear policies and rules which are imposed on the academicians themselves. This paper will also benefit the reader in many ways, bridging the gap in their knowledge and filling the missing piece in the legislative world to guide as many people in the betterment of the country.

\section{Conclusion}

This study is the furtherance of the previous study, which has emphasized the legal analysis of plagiarism in Malaysia. The authors have conducted some in-depth interview sessions with discreetly selected academicians in Malaysian universities to look into their perspectives on plagiarism's legal application. In the end, the study still believes that the regulation relating to plagiarism which the forenamed universities enact must be applied to all Malaysian educational institutions. To enhance the institutions' values and upholding legal responsibility, the administrators and faculties in Malaysian educational institutions shall take a right and responsible step to formulate and enforce the clear academic regulation relating to the academic misconduct of plagiarism. When the academicians have followed the policies or the universities' regulations, a good or perhaps a better quality of research writing can be successfully produced. It is highly recommended for the Ministry of Higher Education (MoHE) to revise the legislation by updating the primary Act or merely merging multiple current policies and rules of the above-stated universities to generate a regulatory framework that governs all universities and establishes consistent standard legislation (Mohd Zain et al., 2021).

Above all, plagiarism is dangerous if the educational institutions themselves do not take any legal action to deal with it. It may result in the universities' academicians losing their academic integrity while producing mysterious yet questionable sourced outcomes in many fields of knowledge. Therefore, this plagiarism issue in academic writing is a serious problem that needs a quick reform to the legal framework. Since there have not been any clear and specific provisions stated on the unethical and misconduct of academicians, especially in plagiarism, the research suggests that universities should adopt a proper provision on the issue. The government is required to do something which can inculcate ethics and professionalism in society as a whole. This unhealthy act cannot be an excuse only because the institution had pressure academicians to write and publish their work.

The study's limitation involves the matter of actual statistical numbers as most cases arise privately in each university, and little information has been collected and analyzed as it has only included interviews with a few researchers from selected universities; thus, it might not represent the entire community of researchers in all academic institutions.

Finally, more future studies should be discussed, from the other perspectives of law, including the legal, educational matters such as civil law like Copyright Act, criminal law such as Penal Code, and any other relevant laws. 


\section{References}

Abu Hassan bin Hasbullah v Zukeri bin Ibrahim [2018] 6 MLJ 396 https://www.cljlaw.com/bulletin/?CLJBulletin;2018;14;b;\#COTW205

Abdul Hamid, M. I., Nik Mohammad, N. A. \& Dhillon, G. (2015). Duty of Care of Educational Administrators and Higher Education Institutions in Malaysia. Malayan Law Journal Articles, 1 .

Adiningrum, T. S. (2015). Reviewing Plagiarism: An Input for Indonesian Higher Education. Journal of Academic Ethics, 13(1), 107-120. DOI:10.1007/s10805-015-9226-6

Ahmed, K. (2020). Academic integrity: Challenges and strategies for Asia and the Middle East. Accountability in research, 27(5), 256-270.

Akbar, A., \& Picard, M. (2019). Understanding plagiarism in Indonesia from the lens of plagiarism policy: lessons for universities. International Journal for Educational Integrity, 15(1), 1-17.

Ali Mohamed, Ashgar Ali and Sardar Baig, Farheen Baig and Ahmad, Muhamad Hassan and Ramalingam, Chithra Latha and RV Rajan, R Usha Devi (2019) Workplace misconduct and the requirement of due inquiry: with reference to the practice in Malaysia. Malayan Law Journal, 5, $113-132$.

Aziz, Z. A., \& Silfiani, F. M. (2020). Plagiarism Among Junior Lecturers In Indonesia: How And Why?. Humanities \& Social Sciences Reviews, 8 (3), 86-94, https://doi.org/10.18510/hssr.2020.8310

Dasar Plagiarisme UiTM Dan Pelaksanaannya. Retrieved from https://inqka.uitm.edu.my/main/images/stories/aboutinqka/PekelilingAkademik-

201219Tambahan-DasarPlagiarismaUiTMDanPelaksanaannya.pdf

Eret, E., \& Gokmenoglu, T. (2010). Plagiarism in higher education: A case study with prospective academicians. Procedia-Social and Behavioral Sciences, 2(2), 3303-3307.

Harvey, L. (2020). Research fraud: a long-term problem exacerbated by the clamour for research grants. Quality in Higher Education, 26(3) at p 243. DOI: 10.1080/13538322.2020.1820126.

IIUM Staff Discipline Rules (2015). Office of the Legal Adviser. Retrieved from https://www.iium.edu.my/office/ola/staff-disciplinary-rules-2015.

Ishak, N. K., Haron, H., \& Ismail, I. (2019). Ethical Leadership, Ethical Climate and Unethical Behaviour in Institutions of Higher Learning. KnE Social Sciences, 408-422. DOI 10.18502/kss.v3i22.5064

Ismail, I. R., Pauzi, S. F. M., \& Abd Hadi, K. A. (2012). Students Plagiarism and Copyright Infringement: A Malaysian Legal Perspective.

Kannan, H. K. (2019, 1 July). Education Ministry to investigate plagiarism claim. The News Straits Times. Retrieved from https://www.nst.com.my/news/nation/2019/07/500674/educationministry-investigate-plagiarism-claim.

Majid, M. A. A., Othman, M., Mohamad, S. F., Lim, S. A. H., \& Yusof, A. (2017). Piloting for interviews in qualitative research: Operationalization and lessons learnt. International Journal of Academic Research in Business and Social Sciences, 7(4), 1073-1080.

Ministry of Higher Education 2020, Malaysia, <https://www.mohe.gov.my/en/corporate/aboutus/introduction> accessed 10 November 2020

Mohamed, K., Abdul Samat, N. H., Abd Aziz, A. S., Mohd Noor, N. A., \& Ismail, N. (2018). Academic plagiarism in Malaysia higher education institutions: a legal perspective. International Journal of Law, Government and Communication, 3(13), 245-253.

Mohd Zain, M. I., Rahmat, N. E., Zulkarnain, M. N., \& Awasthi, S. (2021). Plagiarism of Academic Writing in Malaysian Universities: A legal analysis. Environment-Behaviour Proceedings Journal, 6(16), 197-202. https://doi.org/10.21834/ebpj.v6i16.2709

Moten, A. R. (2014). Academic dishonesty and misconduct: Curbing plagiarism in the Muslim world. Intellectual Discourse, 22(2).

Mustapha, R., Hussin, Z., Siraj, S., \& Darusalam, G. (2017). Academic dishonesty among higher education students: The Malaysian evidence (2014 To 2016). KATHA-The Official Journal of the Centre for Civilisational Dialogue, 13(1), 73-93.

Olesen, A. P., Amin, L., \& Mahadi, Z. (2018). In their own words: research misconduct from the perspective of researchers in Malaysian universities. Science and engineering ethics, 24(6), $1755-1776$. 
Saha, R. (2017). Plagiarism, research publications and law. Current Science, 2375-2378.

Shaarani Ismail, Muhammad Zulsyamini Sufian Suri. (2017, 18 November). Plagiarisme adalah jenayah akademik - Sultan Nazrin (Plagiarism is an academic crime, says Sultan Nazrin). Berita Harian.

Retrieved from https://www.bharian.com.my/berita/nasional/2017/11/352173/plagiarisme-adalah-jenayahakademik-sultan-nazrin

Shad Saleem Faruqi. (2012). Regulating staff discipline. Retrieved 19 January 2021 from https://www.thestar.com.my/opinion/columnists/reflecting-on-the-law/2012/01/25/regulatingstaff-discipline

Singh, M. K. M. (2015). Malaysian Public University Students' Attitude Towards Plagiarism. Language \& Communication, 2(2), 133-145.

Sonfield, M. C. (2014). Academic plagiarism at the faculty level: Legal versus ethical issues and a case study. Journal of Academic Ethics, 12(2), 75-87.

The Regulation of the Minister of National Education of the Republic of Indonesia Number 17 Year 2010 on Prevention and Eradication of Plagiarism in Higher Education. Retrieved from https://idr.uin-antasari.ac.id/479/1/Permendiknas-no.-17-tahun-2010-tentang-PencegahanPlagiat.pdf

Universiti Sains Malaysia- Policy on Plagiarism. Retrieved from https://ips.usm.my/index.php/download/category/33-usm-policy-on-plagiarism

Wibowo, D. E., Hijriwati, S. A. A., \& Soeharto, A. (2016). Plagiarism in the Perspective of Ethics and Law. Scientific Journal of PPI-UKM, 3(2), 55-58.

Wijaya, H., \& Gruber, K. E. (2018). Ethics perspective and regulation of plagiarism in Higher Education. International Journal of Humanities and Innovation (IJHI), 1(1), 17-25.

Zejno, B. (2018). Plagiarism in Academic Writing among Students of Higher Learning Institutions in Malaysia: An Islamic Perspective. Journal of Education and Social Sciences, 9(3), 1-14. 